\title{
THE SEASONAL ABUNDANCE OF YOUNG FISH X. THE YEAR 1948
}

\author{
By P. G. Corbin, B.A.
}

Zoologist at the Plymouth Laboratory

\section{(Text-figs. I-2)}

Records of the young fish and plankton of Plymouth off-shore waters taken in $\frac{1}{2} \mathrm{hr}$. oblique hauls of the $2 \mathrm{~m}$. stramin ring-trawl were continued in 1948 . They show an even lower production of young fish than in 1947 and a continued poverty of plankton organisms other than young fish. The dates on which collections were made are given in Table I.

\section{TABle I. Dates on Which Collections were Made, I 948}

All 2 miles east of Eddystone, unless otherwise stated

Jan. Feb. Mar. Apr. May June July Aug. Sept. Oct. Nov. Dec.

\begin{tabular}{|c|c|c|c|c|c|c|c|c|c|}
\hline 6 & 3 & I & $\mathrm{I} 2^{\star}$ & I9 & I & 5 & 4 & 6 & \\
\hline I4 & 9 & IIt & I4 & 25 & 7 & I2 & 9 & I3 & 7 \\
\hline 20 & $\mathrm{I} 2^{\star}$ & $\mathrm{II}^{\star}$ & & & 8 & I9 & I8 & 20 & $\mathrm{I} 2$ \\
\hline 26 & I6 & I5 & & & I4 & 26 & 23 & 28 & 2. \\
\hline & & 23 & & & $2 \mathrm{I}$ & $29^{\star}$ & $\begin{array}{l}30 \\
31\end{array}$ & & $\begin{array}{l}20 \\
2\end{array}$ \\
\hline
\end{tabular}

\section{Table II. Fortnightly average Catches of all Young} FISH EXCLUDING ClUPEIDS, I930-34, 1947 AND 1948

$\begin{array}{ll}\text { I930-34* } & \text { Ist fortnight } \\ \text { (average) } & \text { 2nd fortnight } \\ \text { I947 } & \begin{array}{l}\text { Ist fortnight } \\ \text { 2nd fortnight }\end{array} \\ \text { I948 } & \begin{array}{l}\text { Ist fortnight } \\ \text { 2nd fortnight }\end{array}\end{array}$

Jan. Feb. Mar. Apr. May June July Aug. Sept. Oct. Nov. Dec.

$\begin{array}{rrrrrrrrrrrr}5 & \text { IO } & 27 & \text { IIO } & 635 & 299 & \text { I00 } & \text { I52 } & 48 & \text { II } & 7 & 2 \\ 8 & \text { 15 } & 89 & 374 & 573 & 78 & 85 & 48 & 9 & 6 & 3 & 2 \\ \text { n.r. } & 5 & 6 & 5 & \text { n.r. } & 20 & \text { I0 } & \text { II } & \text { II } & 2 & \text { I } & + \\ 0 & 43 & \text { I3 } & \text { I0 } & 54 & 27 & 5 & \text { I6 } & \text { I } & 0 & + & + \\ + & 3 & \text { I5 } & \text { I2 } & \text { n.r. } & \text { I3 } & 9 & 9 & + & 4 & 0 & \text { I } \\ 0 & \text { I6 } & \text { I5 } & \text { n.r. } & 65 & 32 & \text { I7 } & 5 & 0 & + & + & 0\end{array}$

* Data kindly supplied by Mr F. S. Russell.

n.r., no records. + average of less than $\mathrm{I}$.

The fortnightly averages of all young fish, excluding clupeids, are now too low to be graphed against the same averages for the period 1930-34 as in Fig. I of former reports: they are therefore given numerically in Table II below, with the 1947 averages for comparison. Callionymus spp. and Solea variegata contributed principally to the highest of these fortnightly averages in the 
second half of May; the next highest value in the second half of June was also mainly due to Callionymus spp.

Earlier parts of this series (Russell, I930-47; Corbin, I948) also give a table of the monthly average catches of young fish. These have now fallen to so low

\section{Table III. Monthly Total Catches of Post-larvae per Half-hour Oblique Hauls With 2 M. Stramin RING-TRAWL, I948}

The number of hauls per month is shown by the small figure against each month at the head of the column. $\mathrm{A}+$ is used in the 2 nd, 4 th and 6 th lines to denote monthly average of less than 0.5 .

Total young fish
Monthly average, T.Y.F. Jan. ${ }^{4}$ Feb. ${ }^{4}$ Mar. ${ }^{6}$ Apr. ${ }^{2}$ May ${ }^{2}$ June ${ }^{5}$ July ${ }^{5}$ Aug. ${ }^{6}$ Sept. ${ }^{4}$ Oct. ${ }^{6}$ Nov. ${ }^{6}$ Dec. ${ }^{3}$ Total averages

\begin{tabular}{|c|c|c|c|c|c|c|c|c|c|c|c|c|c|}
\hline 4 & 107 & 406 & 27 & I 49 & I98 & 162 & 83 & 6 & ISI & I & 5 & 1299 & \\
\hline I & 27 & $8 I$ & 14 & 75 & 39 & 32 & I4 & I & 25 & + & 2 & . & $33 I$ \\
\hline $\begin{array}{l}\text { I } \\
+\end{array}$ & $\begin{array}{r}26 \\
6\end{array}$ & $\begin{array}{l}74 \\
\text { 15 }\end{array}$ & $\begin{array}{l}23 \\
12\end{array}$ & $\begin{array}{r}130 \\
65\end{array}$ & $\begin{array}{l}83 \\
17\end{array}$ & $\begin{array}{l}70 \\
14\end{array}$ & $\begin{array}{r}39 \\
6\end{array}$ & $\begin{array}{l}2 \\
+\end{array}$ & $\begin{array}{r}\text { I4 } \\
2\end{array}$ & $\begin{array}{l}I \\
+\end{array}$ & $\begin{array}{l}3 \\
\mathbf{I}\end{array}$ & $\begin{array}{c}466 \\
\ldots\end{array}$ & $\ddot{138}$ \\
\hline 3 & $8 I$ & 332 & 4 & 19 & II5 & 92 & 44 & 4 & I37 & 0 & 2 & 833 & $\because$ \\
\hline I & 20 & 66 & 2 & ro & 23 & 18 & 7 & I & 23 & 0 & I & .. & 172 \\
\hline . & $\cdots$ & $\cdots$ & $\cdots$ & $\cdots$ & $\cdots$ & $\cdots$ & $\cdots$ & . & $\cdots$ & $\cdots$ & . & . & $\cdots$ \\
\hline . & $\cdots$ & $\cdots$ & $\cdots$ & $\cdots$ & $\cdots$ & $\cdots$ & $\cdots$ & . & . & . & . & 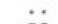 & 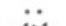 \\
\hline$\cdots$ & $\cdots$ & I & I & 5 & 4 & 2 & $\cdots$ & $\cdots$ & $\cdots$ & * & . & ${ }^{13}$ & 4.4 \\
\hline$\ddot{I}$ & $\cdots$ & $\begin{array}{r}7 \\
16\end{array}$ & 1 & $\cdots$ & $\cdots$ & $\cdots$ & $\cdots$ & $\cdots$ & $\cdots$ & $\ddot{x}$ & 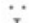 & 8 & $\begin{array}{l}I^{\circ} 9 \\
\end{array}$ \\
\hline . & $\therefore$ & $\ldots$ & 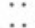 & $\because$ & $\cdots$ & $\cdots$ & $\cdots$ & $\cdots$ & $\cdots$ & 1 & 1 & 19 & 3.45 \\
\hline$\cdots$ & .. & . & 5 & 20 & $\ddot{2}$ & $\because$ & $\because$ & $\because$ & $\cdots$ & $\because$ & $\cdots$ & $\ddot{i}$ & $\because 0^{\circ}$ \\
\hline$\cdots$ & .. & .. & . & . &. & . & 0 & . & $\because$ & . & $\ddot{*}$ & 27 & $\begin{array}{r}12.9 \\
0.3\end{array}$ \\
\hline$\cdots$ & .. & .. & . & $\cdots$ & . & . & . & . & . & $\ldots$ & $\ddot{*}$ & 1 & 0.3 \\
\hline - & $\cdots$ & .. & .. & $\cdots$ & $\cdots$ & $\cdots$ & $\cdots$ & . & .. & . & . & .. & $\because$ \\
\hline$\cdots$ & . & .. & . & . & $\cdots$ & $\cdots$ & . & . & $\cdots$ & $\cdots$ & . & .. & . \\
\hline$\cdots$ & $\cdots$ & $\cdots$ & $\cdots$ & $\cdots$ & $\cdots$ & $\cdots$ & $\cdots$ & . & I & $\cdots$ & . . & I & 0.17 \\
\hline$\cdots$ & $\cdots$ & $\cdots$ & $\cdots$ & $\cdots$ & $\cdots$ & $\cdots$ & . & . & $\cdots$ & $\cdots$ & $\cdots$ & . & $\therefore$ \\
\hline$\cdots$ & $\cdots$ & $\cdots$ & $\cdots$ & $\cdots$ & $\cdots$ & 13 & II & . & 7 & $\cdots$ & . & $3 I$ & 5.57 \\
\hline$\cdots$ & $\cdots$ & $\cdots$ & $\cdots$ & $\cdots$ & $\cdots$ & I & 3 & . & $\cdots$ & $\cdots$ & . & 4 & 0.7 \\
\hline$\cdots$ & $\cdots$ & . & $\cdots$ & 6 & 6 & $\cdots$ & . & . & . & $\cdots$ & . & 12 & $4 \cdot 2$ \\
\hline - & $\cdots$ & $\cdots$ & $\cdots$ & $\cdots$ & I & $\cdots$ & $\cdots$ & $\cdots$ & $\cdots$ & $\cdots$ & . & I & 0.2 \\
\hline$\cdots$ & $\cdots$ & 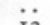 & $\cdots$ & . & 2 & $\cdots$ & $\cdots$ & $\cdots$ & $\cdots$ & $\cdots$ & . & 2 & 0.4 \\
\hline$\cdots$ & $\cdots$ & 13 & $\cdots$ & $\cdots$ & $\cdots$ & $\cdots$ & $\cdots$ & . & $\cdots$ & $\cdots$ & . & I3 & 2.6 \\
\hline$\cdots$ & $\cdots$ & $\cdots$ & $\cdots$ & 5 & I & $\cdots$ & $\cdots$ & $\cdots$ & $\cdots$ & $\cdots$ & . & 6 & $2 \cdot 7$ \\
\hline$\cdots$ & $\cdots$ & . & $\cdots$ & $\cdots$ & $\cdots$ & $\cdots$ & $\cdots$ & $\cdots$ & $\cdots$ & $\cdots$ & $\cdots$ & $\cdots$ & $\cdots$ \\
\hline * & $\cdots$ & $\cdots$ & $\cdots$ & $\cdots$ & $\cdots$ & $\cdots$ & $\cdots$ & . & $\cdots$ & $\cdots$ & . & $\cdots$ & $\cdots$ \\
\hline$\cdots$ & $\cdots$ & $\cdots$ & $\cdots$ & $\ddot{B}$ & $\cdots$ & $\cdots$ & $\cdots$ & $\cdots$ & $\cdots$ & $\cdots$ & . & 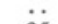 & $\ddot{6}$ \\
\hline - & $\cdots$ & $\cdots$ & $\cdots$ & 33 & 2 & $\cdots$ & $\cdots$ & . & $\cdots$ & $\cdots$ & $\cdots$ & 35 & 16.9 \\
\hline$\cdots$ & $\cdots$ & $\cdots$ & $\cdots$ & $\cdots$ & $\cdots$ & I & 2 & . & I & $\cdots$ & . & 4 & 0.7 \\
\hline$\cdots$ & $\cdots$ & $\cdots$ & . & $\cdots$ & $\cdots$ & $\because$ & $\cdots$ & . & $\cdots$ & $\cdots$ & . & $\because$ & $\therefore$ \\
\hline$\cdots$ & $\cdots$ & $\cdots$ & $\cdots$ & $\cdots$ & $\cdots$ & I & $\cdots$ & $\cdots$ & $\cdots$ & $\cdots$ & $\cdots$ & I & 0.2 \\
\hline$\cdots$ & $\cdots$ & $\cdots$ & . & $\cdots$ & $\cdots$ & 9 & 4 & $\cdots$ & 2 & $\cdots$ & $\cdots$ & I5 & 2.8 \\
\hline$\cdots$ & $\cdots$ & $\cdots$ & $\cdots$ & $\cdots$ & $\cdots$ & I & $\cdots$ & $\cdots$ & $\cdots$ & $\cdots$ & $\cdots$ & I & 0.2 \\
\hline$\cdots$ & $\cdots$ & $\cdots$ & $\cdots$ & $\because$ & $\cdots$ & $\cdots$ & $\cdots$ & . & $\cdots$ & $\cdots$ & . & 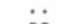 & . \\
\hline$\cdots$ & $\cdots$ & $\cdots$ & 5 & I & 2 & 4 & $\cdots$ & $\cdots$ & $\cdots$ & $\cdots$ & $\cdots$ & 12 & $4 \cdot 2$ \\
\hline$\cdots$ & $\cdots$ & $\cdots$ & I & . & $\cdots$ & I & . & . & $\cdots$ & . & . & 2 & 0.7 \\
\hline . & $\because$ & $\ddot{*}$ & I & $\cdots$ & $\cdots$ & $\cdots$ & $\cdots$ & . & $\cdots$ & $\cdots$ & $\cdots$ & I & 0.5 \\
\hline . & 12 & I3 & 2 & . & . & . & . & . & $\cdots$ & $\cdots$ & . & 27 & 6.6 \\
\hline$\cdots$ & $\cdots$ & . & . & $\therefore$ & $\cdots$ & 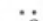 & I & I & .. & $\cdots$ & . & 2 & 0.42 \\
\hline$\cdots$ & $\cdots$ & 2 & 7 & 60 & 27 & 8 & 4 & . & I & $\cdots$ & . & 109 & $41 \cdot 6$ \\
\hline . & $\cdots$ & $\cdots$ & $\cdots$ & $\cdots$ & 2 & I & $\cdots$ & . & . & . & . & 3 & 0.6 \\
\hline$\cdots$ & $\cdots$ & $\cdots$ & $\cdots$ & $\cdots$ & $\ddot{i}$ & $\ddot{Z}$ & $\cdots$ & $\cdots$ & $\cdots$ & $\cdots$ & $\cdots$ & $\ddot{i}$ & $\ddot{x}=n$ \\
\hline$\cdots$ & $\cdots$ & $\cdots$ & $\cdots$ & $\cdots$ & 20 & 12 & I & $\cdots$ & $\cdots$ & $\cdots$ & $\cdots$ & 33 & 6.57 \\
\hline$\cdots$ & $\cdots$ & $\cdots$ & $\cdots$ & $\cdots$ & $\cdots$ & $\because$ & 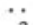 & . & $\cdots$ & $\cdots$ & . & $\cdots$ & $\therefore$ \\
\hline$\cdots$ & $\cdots$ & $\cdots$ & . & $\cdots$ & $\cdots$ & I & 3 & $\cdots$ & $\cdots$ & $\cdots$ & $\cdots$ & 4 & 0.7 \\
\hline$\cdots$ & $\cdots$ & $\cdots$ & . & $\cdots$ & $\cdots$ & 3 & I & $\cdots$ & . & $\cdots$ & $\cdots$ & 4 & 0.77 \\
\hline$\cdots$ & I & $\cdots$ & $\cdots$ & $\cdots$ & 4 & 3 & I & I & $\cdots$ & . & $\cdots$ & I0 & 2.07 \\
\hline . & $\cdots$ & $\cdots$ & $\cdots$ & . & $\cdots$ & I & I & . & $\cdots$ & . & $\ldots$ & 2 & 0.37 \\
\hline$\cdots$ & $\cdots$ & $\cdots$ & . & $\cdots$ & $\cdots$ & $\cdots$ & $\because$ & . & $\cdots$ & $\cdots$ & $\cdots$ & $\cdots$ & 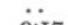 \\
\hline 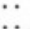 & $\because$ & $\because$ & $\cdots$ & $\cdots$ & $\because$ & $\because 6$ & $\frac{1}{5}$ & $\cdots$ & $\because$ & $\cdots$ & 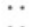 & $\begin{array}{r}1 \\
20\end{array}$ & 0.17 \\
\hline$\ldots$ & $\ddot{1}_{3}$ & $\ddot{1} \dot{8}$ & $\therefore$ & $\ddot{*}$ & $\begin{array}{l}y \\
\ldots\end{array}$ & $\ldots$ & $\therefore$ & $\ddot{*}$ & $\because$ & 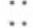 & $\because$ & $3 \mathrm{I}$ & 6.85 \\
\hline$\cdots$ & $\therefore$ & $\cdots$ & . & $\cdots$ & $\cdots$ & $\cdots$ & $\cdots$ & . & $\cdots$ & $\cdots$ & I & I & 0.33 \\
\hline$\cdots$ & $\cdots$ & $\cdots$ & . & $\cdots$ & $\cdots$ & $\cdots$ & $\cdots$ & $\cdots$ & $\cdots$ & . & $\cdots$ & . & . \\
\hline . & $\cdots$ & 3 & $\cdots$ & $\cdots$ & I & $\cdots$ & $\cdots$ & . & . & $\cdots$ & $\cdots$ & 4 & 0.8 \\
\hline$\cdots$ & $\cdots$ & $\cdots$ & $\cdots$ & $\cdots$ & $\cdots$ & $\cdots$ & $\cdots$ & $\cdots$ & $\cdots$ & $\cdots$ & $\cdots$ & $\cdots$ & $\cdots$ \\
\hline$\because$ & $\cdots$ & $\cdots$ & $\cdots$ & $\cdots$ & $\cdots$ & $\cdots$ & $\cdots$ & $\cdots$ & $\cdots$ & $\cdots$ & $\cdots$ & $\cdots$ & $\cdots$ \\
\hline 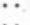 & $\cdots$ & $\cdots$ & $\cdots$ & $\cdots$ & $\cdots$ & $\cdots$ & $\cdots$ & $\cdots$ & $\cdots$ & $\cdots$ & $\cdots$ & $\cdots$ & $\cdots$ \\
\hline$\because$ & $\because$ & 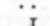 & 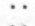 & $\cdots$ & $\because$ & $\ddot{2}$ & $\ddot{r}$ & . & $\ddot{z}$ & $\cdots$ & $\cdots$ & $\ddot{6}$ & $\ddot{x}$ \\
\hline & & & & & & & 1 & & 2 & & $\cdots$ & & \\
\hline
\end{tabular}


a level for almost all species that it is considered more informative to show the monthly total catches for species (Table III) rather than the monthly average catches, many of which are now considerably less than one. For comparison with previous records, the sums of the monthly averages for the year are given in the last column of this table, and the monthly averages of (i) total young fish, (ii) total young fish less clupeids, and (iii) total clupeids are also shown (2nd, 4th and 6th lines, in black). The number of hauls per month is included so that the monthly averages for the species are immediately derivable.

A few young plaice, Pleuronectes platessa, again occurred this year, in March. A single specimen of Mugil spp. was taken on I5 December: in 1947 another single specimen was caught at E I, on I3 November (this haul was not included in the 1947 data).

A young specimen $(33 \mathrm{~mm}$.) of Phycis was also taken in the haul of I5 December this year. It very probably belongs to P. blennioides as this is the only Phycis species occurring in the area. No young stages of this genus have previously been recorded off Plymouth.

As already mentioned, plankton other than young fish was very scarce throughout the year. The maximum haul of Calanus (adult and stage V) contained 280 odd specimens (I June I948), and only four other catches during the year contained more than Ioo Calanus. This, when compared with the rich catches of I930 (Russell, I933), gives some indication of the present poverty. In 1930, thirty-four of the forty-four hauls taken during the year contained more than Ioo Calanus and seventeen out of the forty-four had catches of over I000: the maximum haul contained the very large total of 318,450 specimens (7 May I930).

Sagitta setosa was the dominant Sagitta species throughout the year (Figs. I and 2). It was, however, considerably less numerous than in 1947: on only two occasions were catches of more than Iooo taken (I March, 3I August; I 200 odd). As in 1947, it was almost completely absent during the period April-July. The occurrence of $S$. elegans was very intermittent during the year and the numbers caught were extremely small (maximum, ten specimens).

A particularly noticeable feature of the $S$. setosa catches throughout the year was the preponderance of very small immature specimens (Stages I and II; Russell, I932a). This departure from the normally expected proportions of development Stages (I-III) in the catches would appear to indicate an unusually low survival of individuals reaching maturity. Measurements and counts, comparable with those made by Russell (1932 $b$ ), are required for verification of this trend. It is, however, felt that it should not remain unrecorded, since it may possibly represent a further aspect of the continued and progressive impoverishment of the macroplankton caught by the $2 \mathrm{~m}$. ringtrawl in this area.

Except during April, Muggiaea atlantica was present during all months of 

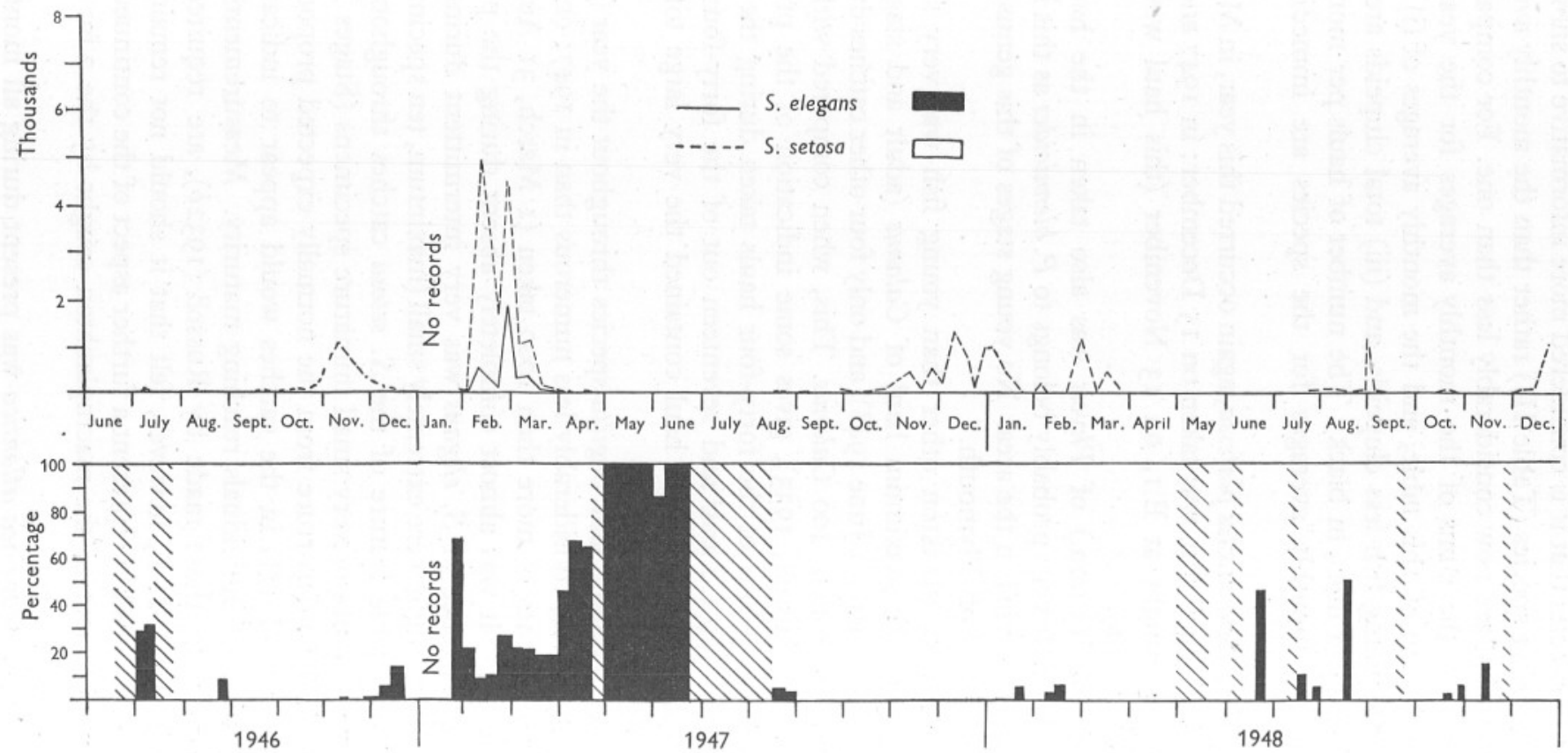

Fig. I. Above, curves showing the actual abundance of Sagitta elegans $(-)$ and S. setosa (-----) in half-hour oblique hauls with the $2 \mathrm{~m}$. stramin ring-trawl during the period June 1946 to December 1948. Below, percentage composition of the Sagitta populations during the same period: S. elegans, black; S. setosa, white; no Sagitta, hatched. (Continued from Corbin, I948, p. 720, fig. 2.) 
the year: it was numerous from the end of July until the end of August and again from the end of September until the end of October.

M. kochi, which was present in very small numbers in I946 (Russell, I947) but did not occur in 1947 (Corbin, I948), was also represented in the catches throughout the year except during February and April. It did not generally exceed one-third of the numbers of $M$. atlantica. In the earlier part (JanuaryJune) and at the end of the year (November and December), the catches of both Muggiaea species were small.

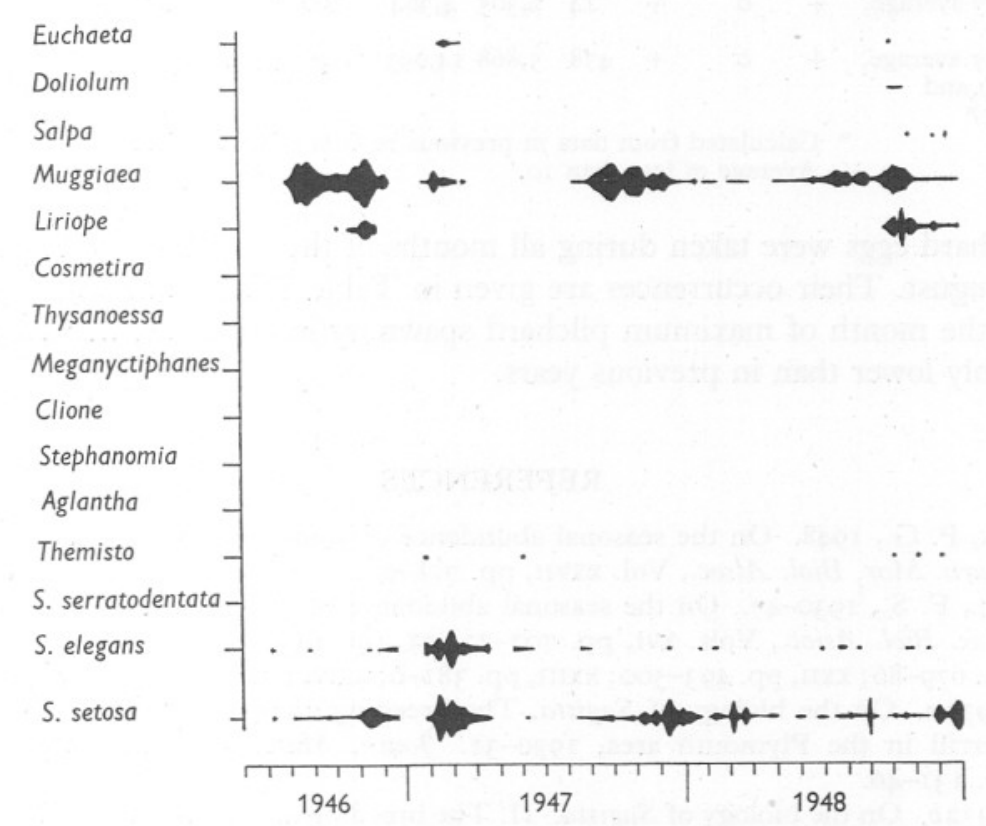

Fig. 2. Diagram showing the occurrence of the various plankton indicators in the collections off Plymouth during the period June 1946 to December I948. (Continued from Corbin, I948, p. 72 I, fig. 3.)

At the end of September (28th), Liriope appeared in considerable numbers. It continued until the end of the year in the catches, although only in small numbers in November and December.

Salps occurred on three occasions (27 October (35), 30 November (I), I5 December (69)), and doliolids were taken twice in October (4th (25), 2Ist (3)).

Three specimens of Euchaeta hebes also occurred in the catch of 4 October, and the hyperiid amphipod, Themisto was present in three hauls at the end of the year (4 October (I), 4 November (II), 6 December (I)).

Beroe was present during October, November and December, and Aequorea pensilis occurred in some numbers during November and December. Mr F. S. Russell kindly identified the Aequorea specimens. 


\section{Table IV. Pilchard Egg Catches, 1948}

See Table I for dates of hauls.

Jan. Feb. Mar. Apr. May June July Aug. Sept. Oct. Nov. Dec.

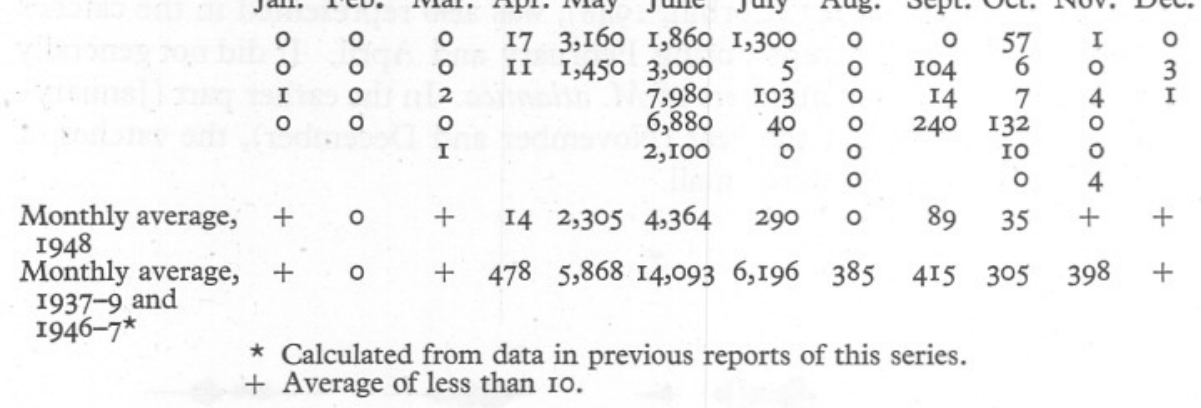

Pilchard eggs were taken during all months of the year except in February and August. Their occurrences are given in Table IV. The average catch in June, the month of maximum pilchard spawning in this area, was very considerably lower than in previous years.

\section{REFERENCES}

Corbin, P. G., I948. On the seasonal abundance of young fish. IX. The year I947. fourn. Mar. Biol. Assoc., Vol. xxviI, pp. 718-22.

RUSSELL, F. S., I930-47. On the seasonal abundance of young fish. I-VIII. Fourn. Mar. Biol. Assoc., Vols. xvI, pp. 707-22; xx, pp. I47-79 and pp. 595-604; xxI, pp. 679-86; xxII, pp. 493-500; XxIII, pp. 38I-6; xxIv, pp. 265-70; XXvI, pp. 605-8. I932a. On the biology of Sagitta. The breeding and growth of Sagitta elegans Verrill in the Plymouth area, 1930-31. Fourn. Mar. Biol. Assoc., Vol. xviII, pp. I3I-46.

- I932 $b$. On the biology of Sagitta. II. The breeding and growth of Sagitta setosa. J. Müller in the Plymouth area, I930-3I, with a comparison with that of S. elegans Verrill. Fourn. Mar. Biol. Assoc., Vol. xvIII, pp. I47-60.

1933. The seasonal distribution of macroplankton as shown by catches in the 2 metre stramin ring-trawl in off-shore waters off Plymouth. fourn. Mar. Biol. Assoc., Vol. xIx, pp. 73-82. 